\title{
THE BADENIAN CALCAREOUS NANNOPLANKTON FROM TURDA AND OCNA DEJ SALT MINES (TRANSYLVANIAN BASIN, ROMANIA)
}

\author{
CARMEN CHIRA ${ }^{1}$
}

\begin{abstract}
Middle Miocene (Middle Badenian, respectivelly Wielician) clays interlayered with the salt deposits from Turda and Ocna Dej salt mines of the Transylvanian Basin have been analysed. The assemblages of calcareous nannoplankton/nannofossils and their significance are presented. Nannofloras are scarce and poorly preserved. The fossil index for NN5 Zone - Sphenolithus heteromorphus appears very rarely, only in few samples. The assemblages can be considered to belong to the upper part of the NN5 Zone and also to the lower part of the NN6 Zone.
\end{abstract}

KEYWORDS: Middle Miocene (Middle Badenian), Transylvanian Basin: Turda, Ocna Dej, calcareous nannoplankton, NN5b, NN6a zones, salt mines.

\section{INTRODUCTION}

The deposits of chemical precipitation from the Transylvanian Basin (Middle Badenian $=$ Wiellician) located on the top of Dej Formation were included by Popescu (1972) in the Mireş Formation, which contains "Ocna Dejului Member", the "radiolarian shales" and the "Spirialis marls".

Mészáros (1991) denominated the chemical precipitation deposits as "Ocna Dejului Beds".

The Middle Badenian (= Wielician) deposits are represented by salt in Turda and Ocna Dej areas, and gypsum in Cheia quarry (Ocna Dejului Formation) (Cluj county).

On the western border of the Transylvanian Basin, Filipescu (1996) denominated the gypsum deposits as Cheia Formation (Middle Badenian), occuring in Copăceni - Sănduleşti - Cheia area. Also, the Cheia Formation is considered to be an equivalent of the "Ocna Dejului Member" established for the deeper salt facies, present in diapiric structures east from the border of the basin (Filipescu, 1996).

Chira $(1999,2000)$ utilized the term "Ocna Dejului Formation" for the deposits of chemical precipitation.

Mészaros, et al. (1989), based on calcareous nannoplankton, considered the salt deposits from Turda area as belonging to the upper part of the NN5 Zone. Generally, the salt from the Transylvanian Basin was considered to belong to the upper part of the Early Badenian.

1 "Babeş-Bolyai" University, Department of Geology, Str. Kogălniceanu 1, 3400 Cluj-Napoca, Romania. 


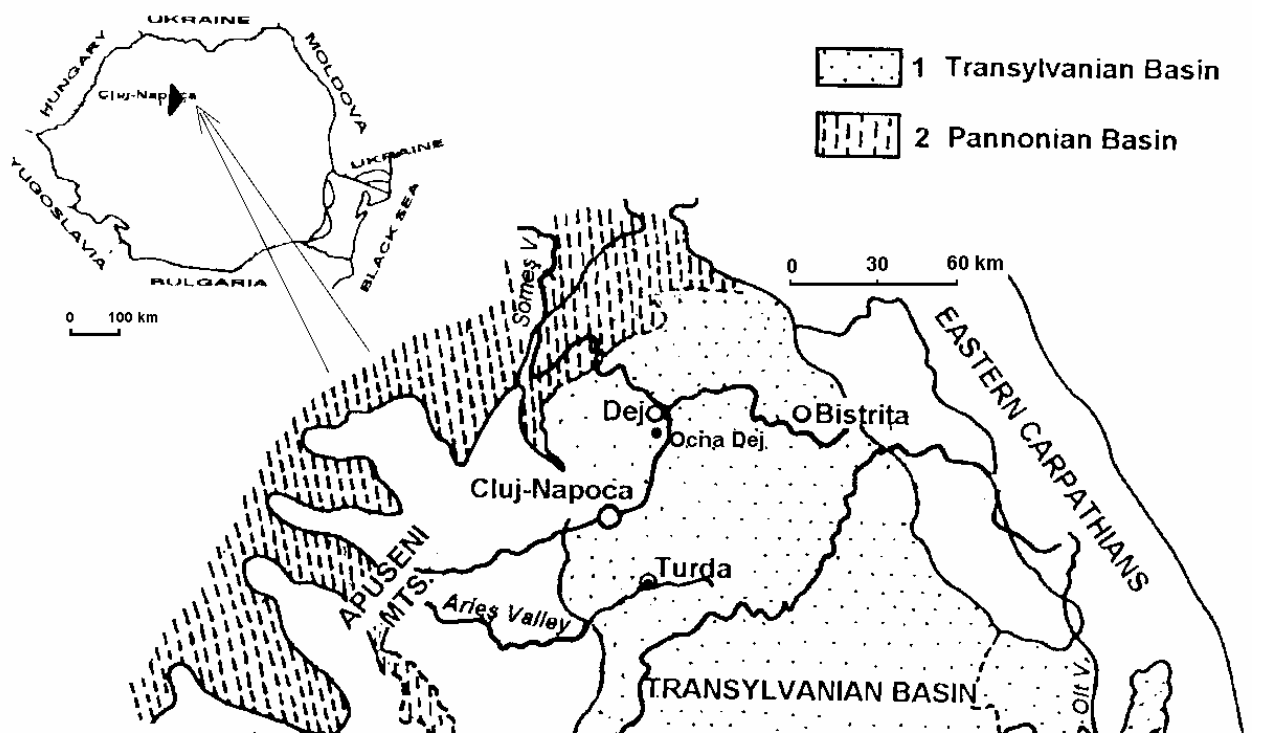

Fig. 1. Location map of the studied salt mines: Turda and Ocna Dej.

\section{GENERAL DATA ABOUT THE BADENIAN CALCAREOUS NANNOPLANKTON}

The calcareous nannoplankton assemblages of Badenian age belong to NN5 Zone - with Sphenolithus heteromorphus and to NN6 Zone - with Discoaster exilis, according to the Standard Nannoplankton Zonation (Martini, 1971).

The Badenian sediments from Cheia quarry - with gypsum - have been considered to belong to NN5 and NN6 Zones (the upper part of the deposits overlaying the gypsum) (Mészáros in Ghergari et al., 1991). Mărunțeanu (in Popescu et al., 1995) considered them to belong to NN6 Zone.

The Badenian nannoplankton bioevents from the Transylvanian Basin and Muntenian and Moldavian Subcarpathians have been established by Mărunțeanu \& Chira (1998).

Concerning the calcareous nannofossils, some features were evidenced for the Badenian (Moravian, Wielician, and Kossovian) of the intra- Carpathian and also extra- Carpathian area (Mărunțeanu \& Chira, 1998):

The lower boundary of the Badenian, corresponding to the beginning of NN5 Zone, cannot be correlated with the beginning of the Langhian, characterized by the upper part of NN4 Zone.

The Moravian is characterized by the NN5 Zone assemblage, its lower boundary corresponding to the extinction of Helicosphaera ampliaperta and/or the first occurrences of Discoaster exilis. 
The Wielician can be defined as the time interval beginning with the first appearance of Discoaster brouweri, being indicated by the upper part of NN5, and the lower part of NN6 zones.

The Kosovian covers the majority of NN6 Zone, its upper boundary being marked by the extinction of Cyclicargolithus floridanus.

The Badenian top was defined by NN7 Zone beginning by Müller, (1974), Fuchs \& Stradner (1977), Rögl \& Müller (1976), Mészáros (1991) a. o.

NN5 Zone was defined by Bramlette \& Wilcoxon (1967), between the last occurrences of Helicosphaera ampliaperta and the last appearances of Sphenolithus heteromorphus.

The nannofossil content of Sphenolithus heteromorphus Zone (NN5) consists of Sphenolithus heteromorphus, Discoaster exilis, Discoaster musicus, Discoaster variabilis, Holodiscolithus macroporus, etc.

Discoaster brouweri, Helicosphaera wallichii and Sphenolithus abies have simultaneous first occurrences before the last appearance of Sphenolithus heteromorphus.

The Sphenolithus heteromorphus Zone can be correlated with the following foraminifera zones: Candorbulina glomerosa, and Candorbulina universal Globorotalia bykovae (defined by Popescu, 1970), characterizing the Early Badenian, then with the basis of Globigerina druryilGloborotalia transsylvanica (defined by Popescu \& Gheța, 1984), which indicates the debut of Middle Badenian.

The Discoaster exilis Zone (NN6) (Martini \& Worsley, 1970) includes the stratigraphic interval between the extinction of Sphenolithus heteromorphus and the first occurrence of Discoaster kugleri. Its upper boundary can also be approximated by the last appearances of Cyclicargolithus floridanus.

Its lower part is characterized by the explosive development of Discoaster brouweri and the presence of rare Triquetrorhabdulus rugosus.

The nannoplankton content, specific to the Discoaster exilis Zone, consist of Discoaster brouweri, Discoaster exilis, Discoaster variabilis, Helicosphaera wallichii, Sphenolithus abies, Triquetrorhabdulus rugosus, Syracolithus dalmaticus, Scapholithus fossilis, Helicosphaera walbersdorfensis etc., that occur at different stratigraphic levels.

The NN6 Zone can correlate to Globigerina druryilGloborotalia transsylvanica and Velapertina foraminifera Zones, which characterize the Middle, and respectively the Late Badenian.

In the stratigraphic distribution of the Badenian nannofossils from the intra(and also extra-) Carpathian areas, the bioevents which have been noticed concerning the Wielician, are the following (after Mărunțeanu \& Chira, 1998):

- the first simultaneous appearances of Discoaster brouweri, Helicosphaera wallichii and Sphenolithus abies, before the extinction of Sphenolithus heteromorphus, in the upper part of Dej Formation;

- the first appearances of Triquetrorhabdulus rugosus and Helicosphaera stalis, accompanied by the explosive development of Discoaster brouweri simultaneously occurring in the basal parts of Ocna Dej and/or Mireş Formations;

- the explosive development of Reticulofenestra pseudoumbilicus with its "gelida" and „pseudoumbilicus" subspecies, in the basal part of Câmpia Turzii Formation or within Mireş Formation. 
Further, the subzones corresponding to the Wielician (Mărunțeanu et al., 2000) have been established, based on detailed studies of the Badenian calcareous nannofossils of Romania, which permitted the establishment of many bioevents, very important for regional and worldwide biostratigraphic correlations. On their basis, the Sphenolithus heteromorphus - NN5 and Discoaster exilis - NN6 standard zones, which exclusively characterize Badenian nannoplankton assemblages, were subdivided into several subzones, as follows: Geminilithella rotula - NN5a, that defines the Moravian Substage; Helicosphaera wallichii - NN5b and Discoaster variabilis - NN6a, typical for Wielician Substage; Syracosphaera histrica - NN6b, Syracolithus dalmaticus - NN6c and Calcidiscus pataecus - NN6d, which characterize the Kossovian Substage.

Also, in the case of:

- NN5 Zone - with Sphenolithus heteromorphus - (Age: Early - Middle Badenian or Moravian - Earliest Wielician) based on the regional bioevents, two subzones have been defined, their boundary corresponding to the Moravian - Wielician boundary:

- NN5a Subzone - with Geminilithella rotula - (Age: Early Badenian or Moravian), defined by the LO of Helicosphaera ampliaperta to FO of Discoaster brouweri.

- NN5b Subzone - with Helicosphaera wallichii - (Age: Earliest Middle Badenian or Earliest Wielician), defined of the FO of Discoaster brouweri Tan or of Helicosphaera wallichii to LO of Sphenolithus heteromorphus. The characteristic nannofossil assemblage of this subzone contains the same typical NN5 Zone species associated with Helicosphaera wallichii and Discoaster brouweri.

- NN6 Zone - with Discoaster exilis - (Age: Middle Badenian = Wielician and Late Badenian $=$ Kossovian).

It was noticed that in the Central Paratethys, the beginning of NN6 zone can be approximated with FO of Triquetrorhabdulus rugosus Bramlette \& Wilcoxon, 1967 and the abundance of Cyclicargolithus floridanus, that decreases towards the top of the biozone.

NN6 Zone - with Discoaster exilis has been divided into several subzones which allow a precise dating of the Badenian deposits (Mărunțeanu et al., 2000), among which:

- NN6a Subzone - with Discoaster variabilis (Age: most of Middle Badenian or of Wielician). This subzone was defined between LO of Sphenolithus heteromorphus and FO of Helicosphaera stalis. The calcareous nannofossil assemblage of this subzone contains the same species as NN5b Subzone (excepting Sphenolithus heteromorphus) associated with Triquetrorhabdulus rugosus.

It was demonstrated that the Wielician, (after Mărunțeanu et al., 2000), characterized by Helicosphaera wallichii - NN5b and Discoaster variabilis - NN6a subzones, can correlate to the Uppermost Langhian, defined by the uppermost parts of the Eu-discoaster musicus Subzone (Theodoridis, 1984) or Helicosphaera walbersdorfensis/Sphenolithus heteromorphus Subzone (Fornaciari et al., 1996) 
and with the Lowermost Serravallian, defined by Helicosphaera walbersdorfensis and Helicosphaera stalis subzones (Theodoridis, 1984) or Sphenolithus heteromorphus/ Reticulofenestra pseudoumbilicus - MNN6a and Reticulofenestra pseudoumbilicus - MNN6b subzones (Fornaciari et al., 1996).

\section{THE CALCAREOUS NANNOPLANKTON/NANNOFOSSILS FROM} THE SALT

A preliminary study of the calcareous nannoplankton/nannofossils from Turda and Ocna Dej salt mines was realized (Fig. 1).

The samples from the clay intercalations were difficult to prepare and the calcareous nannofossils were generally poorly preserved.

A high frequence of the species Calcidiscus leptoporus (Murray \& Blackmann 1898) Loeblich \& Tappan 1978), Cyclicargolithus floridanus (Roth \& Hay 1967) Bukry 1971, Calcidiscus macintyrei (Bukry \& Bramlette 1969) Loeblich \& Tappan 1978), Coccolithus miopelagicus Bukry 1971, Coccolithus pelagicus (Wallich 1877) Schiller 1930, Triquetrorhabdulus rugosus Bramlette \& Wilcoxon 1967, Sphenolithus abies Deflandre 1954, Sphenolithus moriformis (Broennimann \& Stradner 1960) Bramlette \& Wilcoxon 1967 was noticed in the samples from Turda salt mine, as well as in those from Ocna Dej salt mine. Only in two samples, a single specimen of Sphenolithus heteromorphus Deflandre 1953, the index species for NN5 Zone was present.

The analyse of the samples from both salt mines performed until now evidenced the reduced content of calcareous nannofossils, represented of about 15 species (Tab. 1).

Table 1

Calcareous nannofossils from Turda and Ocna Dej salt mines (according to the classification of Young \& Bown, 1997)

\begin{tabular}{|c|c|c|}
\hline \multirow{2}{*}{ NANNOFOSSIL SPECIES } & \multicolumn{2}{|c|}{ SALT MINES } \\
\hline & TURDA & $\begin{array}{c}\text { OCNA } \\
\text { DEJ }\end{array}$ \\
\hline $\begin{array}{l}\text { CALCAREOUS NANNOPLANKTON: } \\
\text { HETEROCOCCOLITS } \\
\text { Family Pontosphaeraceae }\end{array}$ & & \\
\hline Pontosphaera multipora (KAMPTNER, 1948) ROTH (1970) & $\mathrm{X}$ & \\
\hline Pontosphaera discopora & $\bar{X}$ & $\bar{X}$ \\
\hline \multicolumn{3}{|l|}{ Family Syracosphaeraceae } \\
\hline Syracosphaera histrica KAMPTNER (1941) & $\mathrm{X}$ & $\bar{X}$ \\
\hline \multicolumn{3}{|l|}{ Family Noelaerhabdaceae } \\
\hline Cyclicargolithus floridanus (ROTH \& HAY in HAY et al., 1967) BUKRY (1971) & $\mathrm{X}$ & $\mathrm{X}$ \\
\hline Reticulofenestra pseudoumbilicus (GARTNER, 1967) GARTNER (1969) & $\mathrm{X}$ & \\
\hline \multicolumn{3}{|l|}{ Family Coccolithaceae } \\
\hline Coccolithus miopelagicus BUKRY (1971) & $\mathrm{X}$ & $\bar{X}$ \\
\hline Coccolithus pelagicus (WALLICH, 1877) SCHILLER (1930) & $\mathrm{X}$ & \\
\hline Family Calcidiscaceae & & \\
\hline Calcidiscus leptoporus (MURRAY \& BLACKMAN, 1898) LOEBLICH \& & $\mathrm{X}$ & $\mathrm{X}$ \\
\hline
\end{tabular}




\begin{tabular}{|c|c|c|}
\hline \multirow[t]{2}{*}{ NANNOFOSSIL SPECIES } & \multicolumn{2}{|c|}{ SALT MINES } \\
\hline & TURDA & $\begin{array}{l}\text { OCNA } \\
\text { DEJ }\end{array}$ \\
\hline \multicolumn{3}{|l|}{ TAPPAN (1978) } \\
\hline $\begin{array}{l}\text { Calcidiscus macintyrei (BUKRY \& BRAMLETTE, 1969) LOEBLICH \& } \\
\text { TAPPAN (1978) }\end{array}$ & $\mathrm{X}$ & $\mathrm{X}$ \\
\hline Umbilicosphaera jafari MÜLLER (1974) & & $\mathrm{X}$ \\
\hline $\begin{array}{c}\text { HOLOCOCCOLITHS } \\
\text { Family Calyptrosphaeraceae }\end{array}$ & & \\
\hline $\begin{array}{l}\text { Holodiscolithus macroporus (DEFLANDRE in DEFLANDRE \& FERT, } \\
\text { 1954) ROTH (1970) }\end{array}$ & & $\mathrm{X}$ \\
\hline \multicolumn{3}{|l|}{$\begin{array}{c}\text { NANNOLITHS } \\
\text { Family Discoasteraceae }\end{array}$} \\
\hline Discoaster cf. musicus STRADNER (1959) & & $\mathrm{X}$ \\
\hline \multicolumn{3}{|l|}{ Family Sphenolithaceae } \\
\hline Sphenolithus heteromorphus DEFLANDRE (1953) & $\mathrm{X}$ & $\mathrm{X}$ \\
\hline $\begin{array}{l}\text { Sphenolithus moriformis (BRÖNNIMANN \& STRADNER, 1960) } \\
\text { BRAMLETTE \& WILCOXON (1967) }\end{array}$ & $\mathrm{X}$ & $\mathrm{X}$ \\
\hline Sphenolithus abies DEFLANDRE in DEFLANDRE \& FERT (1954) & $\mathrm{X}$ & $\bar{X}$ \\
\hline \multicolumn{3}{|l|}{ Family Triquetrorhabdulaceae } \\
\hline Triquetrorhabdulus rugosus BRAMLETTE \& WILCOXON (1967) & $\mathrm{X}$ & $\mathrm{X}$ \\
\hline CALCAREOUS DINOFLAGELLATES & & \\
\hline Thoracosphaera heimii (LOHMANN 1919) Kamptner 1941 & $\mathrm{X}$ & \\
\hline Thoracosphaera sp. & $\mathrm{X}$ & $\mathrm{X}$ \\
\hline
\end{tabular}

Reworked forms from Cretaceous and Paleogene, and possibly also from Lower Badenian were quite abundant, especially in the salt mine from Turda.

Besides the calcareous nannofossil species mentioned previously, the assemblage contained also: Reticulofenestra pseudoumbilicus (Gartner 1967) Gartner 1969, Pontosphaera multipora (Kamptner 1948) Roth 1970, Syracosphaera histrica Kamptner 1941, Discoaster cf. musicus Stradner 1959, Umbilicosphaera cf. jafari Mueller 1974, Holodiscolithus macroporus (Deflandre 1954) Roth 1970.

Calcareous dinoflagellates represented by species of Thoracosphaera, very frequent being Thoracosphaera heimii (Lohmann 1919) Kamptner 1941, characterize the samples from Turda salt mine.

\section{CONCLUSIONS}

In conclusion, the data obtained until now on calcareous nannofossils, based on the assemblage with Triquetrorhabdulus rugosus, Cyclicargolithus floridanus, a.o., allow us to attribute the analysed clays from the salt to Wielician.

The extinction of Cyclicargolithus floridanus is considered to mark the limit between NN6/NN7 Zones.

The index species for NN6 - Discoaster exilis was not observed in the analysed samples yet, and Sphenolithus heteromorphus was rarely noticed, the whole assemblage being scarce in calcareous nannofossils as compared to the abundance of nannofloras that generally characterizes the Moravian (Early Badenian) (NN5 Zone - with Sphenolithus heteromorphus).

These observations let us appreciate that this is either the last occurrence of Sphenolithus heteromorphus, or that the species was reworked at this level. 
NN6 Zone - with Discoaster exilis is marked at the upper part by the last appearance of Cyclicargolithus floridanus.

Generally, in Central Paratethys, the beginning of NN6 Zone can be correlated with the first appearance of Triquetrorhabdulus rugosus. The frequence of Cyclicargolithus floridanus is decreasing towards the upper part of the zone.

NN6 Zone is characteristic for Wielician and Kossovian.

In the analysed samples, the presence of two species: Cyclicargolithus floridanus and Triquetrorhabdulus rugosus was frequently observed.

Therefore, in our oppinion the studied deposits can be considered to belong to the upper part of NN5 Zone (NN5b Subzone) and the lower part of NN6 Zone (NN6a Subzone), which correspond to Middle Badenian (Wielician).

\section{REFERENCES}

Bramlette, M. N., Wilcoxon, J. A., 1967, Middle Tertiary Calcareous Nannoplankton of the Cipero Section, Trinidad, W. I. Tulane Studies Geology, 5, p. 93 - 131.

Chira, C., 1999, Middle Miocene calcareous nannoplankton from the western Transylvanian Basin, Romania: Biostratigraphy, taxonomy and palaeoecology. Studia Univ. BabeşBolyai, Geol.-Geogr., XLIV, 2, p. 3 - 75, 6 figs., 2 tab., 7 pl., Cluj-Napoca.

Chira C., 2000, Nannoplancton calcaros şi moluşte miocene din Transilvania. Ed. Carpatica, 183 p., 21 figs., 8 tab., 20 pl., Cluj-Napoca.

Filipescu, S., 1996, Stratigraphy of the Neogene from the western border of the Transylvanian Basin. Studia Univ. Babeş-Bolyai, Geol.-Geogr., XLI, 2, p. 3 - 77, 16 figs., 5 tab., 6 pl., Cluj-Napoca.

Fornaciari, E., Di Stefano, A., Rio, D., Negri, A., 1996, Middle Miocene quantitative calcareous nannofossil biostratigraphy in the Mediterranean region. Micropaleontology, 42, 1, p. 37 63, tex-figs. $1-18$, pl. $1-3$, appendix 1.

Fuchs, R., Stradner, H., 1977, Über Nannofossilien im Badenien (Mittelmiozän) der Zentralen Paratethys. Beitr. Paläont. Österr., 2, p. 1 - 58, 4. Abb., 2 Tab., 8 Taf., Wien.

Ghergari, L., Mészaros, N., Hosu, A., Filipescu, S., Chira, C., 1991, The Gypsiferous Formation at Cheia (Cluj County). Studia Univ. Babeş-Bolyai, XXXVI, 1, p. 13 - 28, Cluj-Napoca.

Martini, E., Worsley, 1970, Standard Nogene calcareous nannoplankton zonation. Nature, 225, p. $289-290$.

Martini, E., 1971, Standard Tertiary and Quaternary Calcareous Nannoplankton Zonation. Proceedings of the II Planktonic Conference, Roma, 1970, A. Farinacci, ed., Ed. Tecnoscienza, p. 739 - 785, Rome.

Mărunțeanu, M., Chira, C., 1998, Marine middle Miocene calcareous nannoplankton: a comparative study of the Subcarpathians and Transylvanian Basin. Abstract. XVI. Carpatho-Balkan Congress, Vienna, 1998.

Mărunțeanu, M., Crihan, M., Chira, C., 2000, Badenian nannofossil zonation - the Carpathian area. Acta Palaeontologica Romaniae, 2, p. 261 - 267, Cluj-Napoca. 


\section{CARMEN CHIRA}

Mészaros, N., Nicorici, E., Filipescu, S., 1989, Le nannoplancton des dépots néogenes saliféres traversés par les forages executés aux environs de la ville Turda. Studia Univ. BabeşBolyai, Geol.-Geogr., XXXIV, 2, Cluj-Napoca.

Mészaros, N., 1991, Nannofossil Zones in the Paleogene and Miocene Deposits of the Transylvanian Basin. Proced. IV. INA Conf., Knihovnicka ZPN, 14 b, 2, p. 87 - 92, 3 fig., Prague.

Müller, C., 1974, Nannoplankton aus dem Mittel-Miozän von Walbersdorf (Burgenland). Senckenbergiana lethaea, 55 (1/5), p. 389 - 405, 4 Taf., Frankfurt am Main.

Popescu, G., 1970, Planktonic Foraminiferal Zonation in the Dej Tuff Complex. Rev. Roum. Géol., Géoph., Géogr., ser. Geol., 14/2, p. 189 - 203, Bucureşti.

Popescu, G., 1972, Biostratigrafia depozitelor oligo-miocene de la sud de Preluca pe bază de foraminifere. D. S. Inst. Geol., LVIII, 3, p. 105 - 127, Bucureşti.

Popescu, G., Gheța, N., 1984, Comparative Evolution of the Marine Middle Miocene Calcareous Microfossils from the Carpathian and Pannonian Areas. D. S. LXIX/3, p. $125-133$, Bucureşti.

Popescu, G., Mărunțeanu, M., Filipescu, S., 1995, Neogene from Transylvania Depression (Guide to Excursion A1 (pre- Congress)), Xth RCMNS Congress, Rom. Journ. Stratigraphy, 76, Suppl. 3, p. 1 - 27, 13 fig., Bucureşti.

Rögl, F., Müller, C., 1976, Das Mittelmiozän und die Baden/Sarmat Grenze in Walbersdorf (Burgenland). Ann. Naturhist. Mus. Wien, 80, p. 221 - 232, 1 Abb., 2 Tab., Wien.

Theodoridis, S., 1984, Calcareous Nannofossil Biozonation of the Miocene and Revision of the Helicoliths and Discoasters. Utrecht Micropal. Bull., 32, p. 3 - 271, 66 figs., A - E text figs.,37 pl., Utrecht

Young, J., R., Bown, P. R., 1997, Cenozoic calcareous nannoplankton classification. Journal of Nannoplankton Research, 19, 1, p. $15-47$.

Plate I: Calcareous nannofossils from Ocna Dej salt mine

Fig. 1a, 1b - Coccolithus cf. miopelagicus Bukry. 1a - NII; $1 \mathrm{~b}-\mathrm{N}+; \times 2.000$.

Fig. 2a, 2b - Coccolithus pelagicus (Wallich) Schiller. $2 a-N I I ; 2 b-N+; \times 2.000$.

Fig. 3a, 3b, 4a, 4b - Cyclicargolithus cf. floridanus (Roth \& Hay) Bukry. 3a, 4a - NII; 3b, $4 \mathrm{~b}-\mathrm{N}+; \times 2.000$.

Fig. 5. Umbilicosphaera jafari Mueller. $\mathrm{N}+; \times 2.000$.

Fig. 6a, 6b-Cyclicargolithus floridanus (Roth \& Hay) Bukry. 6a - NII; 6b - N+; 2.000 .

Fig. 7. - Calcidiscus leptoporus (Murray \& Blackman) Loeblich \& Tappan. N+; 2.000.

Plate II: Calcareous nannofossils from Ocna Dej salt mine

Fig. 1a, 1b - Sphenolithus moriformis (Brönnimann \& Stradner) Bramlette \& Wilcoxon. $1 \mathrm{a}-\mathrm{NII} ; 1 \mathrm{~b}-\mathrm{N}+; \mathrm{x} 2.000$.

Fig. 2a, 2b-Sphenolithus cf. abies Deflandre. $2 \mathrm{a}-\mathrm{NII} ; 2 \mathrm{~b}-\mathrm{N}+; \times 2.000$.

Fig. 3a, 3b, 3c-Sphenolithus heteromorphus Deflandre. 3a-NII; 3b, 3c-N+; 2.000 .

Fig. 4. Triquetrorhabdulus rugosus Bramlette \& Wilcoxon. NII; $x 2.000$.

Fig. 5a, 5b - Thoracosphaera sp. 5a-NII; $5 \mathrm{~b}-\mathrm{N}+;$; 2.000 .

Fig. 6. Thoracosphaera heimii (Lohmann) Kamptner. $\mathrm{N}+; \times 2.000$. 
Plate I

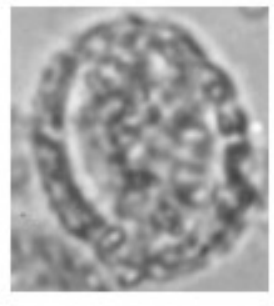

$1 \mathrm{a}$

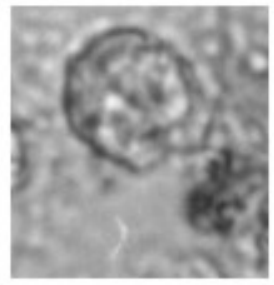

3a

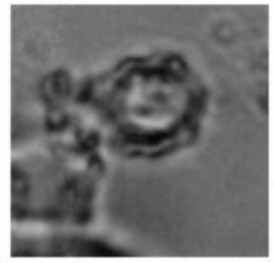

$4 a$

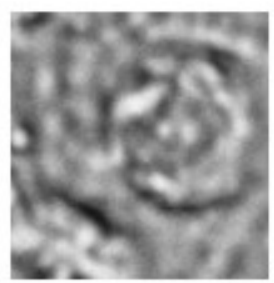

$6 a$

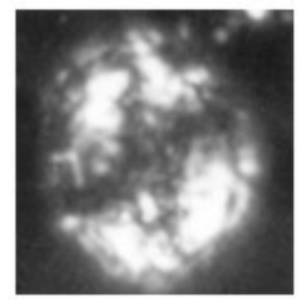

$1 b$

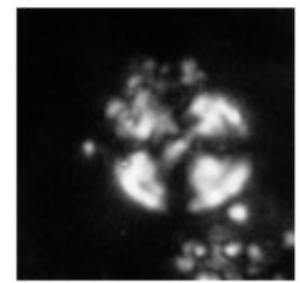

$3 \mathrm{~b}$

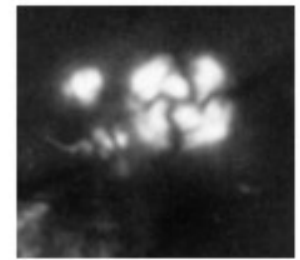

$4 b$

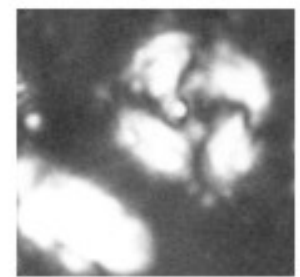

$6 b$

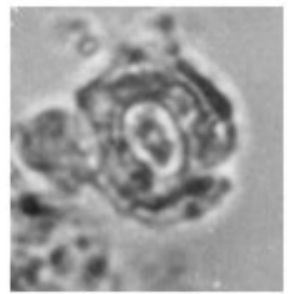

$2 \mathrm{a}$

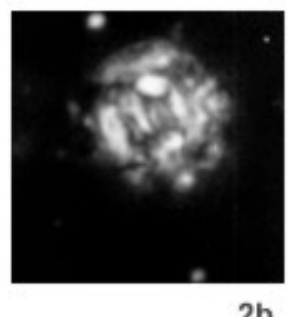

$2 b$
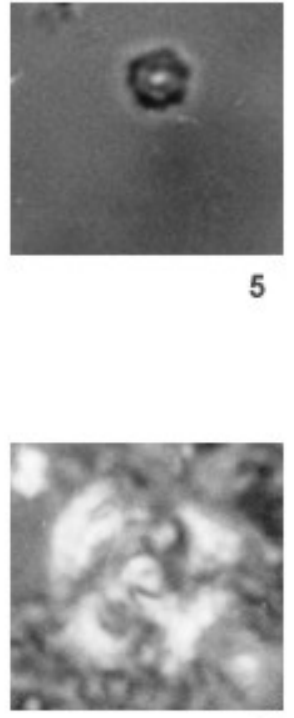

7 
CARMEN CHIRA

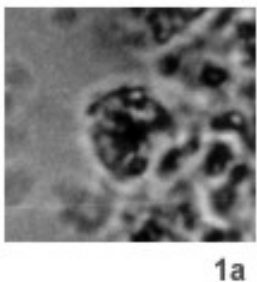

Plate II
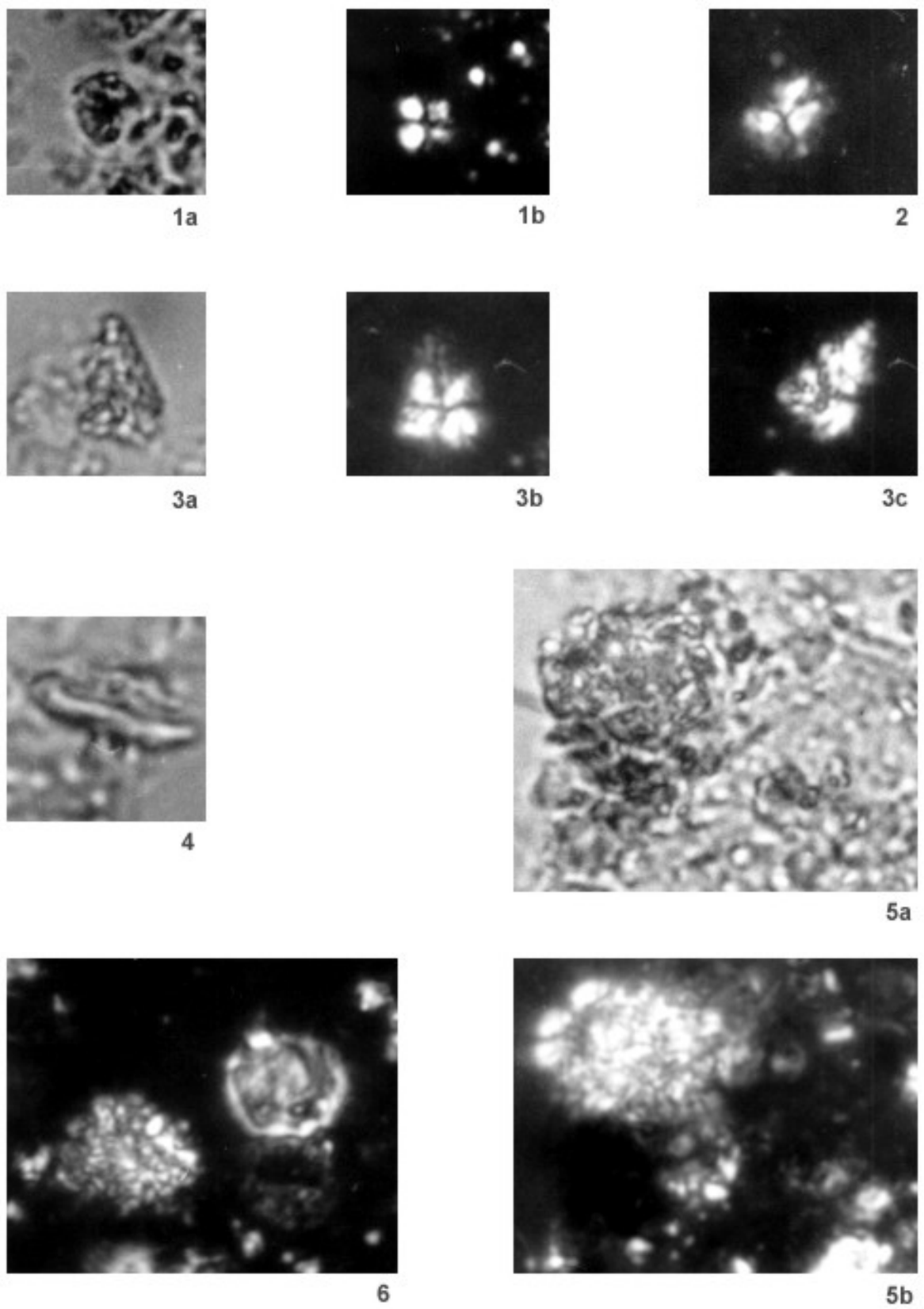